ks. Robert Tyrała

\title{
I Ogólnopolski Kongres Muzyki Liturgicznej Musicam Sacram Promovere na tle wcześniejszych inicjatyw odnowy muzyki kościelnej w Polsce
}

Jedną z form upowszechniania właściwego stylu muzyki kościelnej stały się organizowane przez ośrodki muzyczne w Polsce Kongresy Muzyki Kościelnej. Gromadziły one wielu muzyków, stawały się okazją do wspólnych dyskusji nad kształtem muzyki w liturgii oraz cieszyły się też wielkim poparciem pasterzy Kościoła. Były impulsem do dalszego działania dla odnowy muzyki kościelnej. Warto w tym miejscu zacytować jakże ważną uwagę poczynioną po przeprowadzeniu trzech takich kongresów przez ks. Faustmana: „Z wszystkich trzech kongresów «Muzyka Kościelna» podawała obszerne sprawozdania, w tym celu, ażeby najpierw one były dokumentami tych wielkich wydarzeń w Związku Chórów, a potem ażeby na nich wzorowały się kongresy następne. Każdy z nich miał swoje specyficzne znamiona"1.

Konsekwencją owych wydarzeń z 1931 roku w Krakowie, z 1933 roku w Toruniu oraz z 1958 roku na Jasnej Górze stał się I Ogólnopolski Kongres Muzyki Liturgicznej Musicam Sacram Promovere, który miał miejsce w dniach 17-19 września 2004 roku w Krakowie. Omawiając to wydarzenie „Ruch Muzyczny” pisał: „w Polsce trzęsienie ziemi! Coś niezwykłego? Nie zjawisko naturalne, o którym zapomnieliśmy, bo nawiedza nas rzadko. Podobnie Kościół katolicki w Polsce zapomniał o muzyce... refleksja krytyczna oraz wołanie o pilne i dalekosiężne zmiany w tej dziedzinie"2. Popatrzmy więc na to wydarzenie w kontekście wcześniej podejmowanych prób naprawy muzyki liturgicznej.

\section{Wszechpolski Kongres Muzyki Kościelnej, Kraków 1931}

W dniach 22-23 listopada 1931 roku w Krakowie miał miejsce II Wszechpolski Kongres Muzyki Kościelnej pod hasłem Polska twórczość religijno-muzyczna ${ }^{3}$. We wstępie redakcyjnym „Muzyki Kościelnej”, jakby w przygotowaniu owego wydarzenia czytamy: „wiemy, o co idzie: solidarnie, zszeregowani w naszych organizacjach, dążymy do podniesienia muzyki kościelnej w Polsce, pragnąc przyczynić się wedle sił do pomnożenia dorobku w dziedzinie narodowej kultury muzycznej, która

\footnotetext{
${ }^{1}$ W. Faustman, Uwagi Kongresowe, „Muzyka Kościelna” 9 (1934) nr 7-8, s. 104.

${ }^{2}$ K. Miklaszewski, I Ogólnopolski Kongres Muzyki Liturgicznej Musiam Sacram Promovere, „Ruch Muzyczny” 21 (2004), s. 8.
} 
w lwiej części, schron swój najpewniejszy i rozgłośnie swego piękna na najdalsze zakątki Ojczyzny ma w swych polskich, katolickich świątyniach i parafiach. Dlatego praca nasza przynosi korzyść i pożytek społeczeństwu, stanowiąc zarazem posługę duchową Kościołowi i wiernym”" Było to wydarzenie bardzo ważne w dziedzinie muzyki kościelnej. Jak zauważa ks. Faustman, zgromadziło ono wielu kompozytorów, muzyków kościelnych, chóry kościelne oraz miłośników muzyki kościelnej, a celem miało być nie tylko przypomnienie sobie wielkiej twórczości rodzimych muzyków kościelnych, ale aby „z kongresu wynieść nową podnietę do dalszej pracy na niwie muzyki kościelnej" ". Uroczyste zgromadzenie rozpoczęło się nabożeństwem na Wawelu, podczas którego śpiewał chór Echo pod dyr. Bolesława Wallek-Walewskiego, a bardzo poruszające muzycznie kazanie wygłosił ks. Hieronim Feicht. Po tym nabożeństwie udano się do Domu Katolickiego, gdzie miała miejsce uroczysta akademia inauguracyjna. Tam słowo wstępne wygłosił ks. Władysław Wargowski, który był głównym organizatorem owego kongresu, po nim zaś przemówił kard. Adam Stefan Sapieha (wielki protektor kongresu). On to podkreślił, że „naród, który nie śpiewa, jest narodem umierającym, religia, która nie śpiewa, jest religią umierającą, bo śpiewanie w Domu Bożym jest szczególną i uroczystą modlitwy formą. Zdanie to ma wiele słuszności. Śpiew bowiem i muzyka są tak wrodzone człowiekowi, że wszystkie silniejsze wzruszenia, głębsze uczucia łączą się prawie zawsze z pieśnią i muzyką, a brak ich byłby oznaką stanu anormalnego, chorobą zatruwającą życie"6.

Momentem kulminacyjnym kongresu była msza chóralna 23 listopada w kolegiacie św. Anny, podczas której części stałe śpiewane były przez 700 teologów (klerycy seminarium krakowskiego, częstochowskiego, śląskiego, oo. augustianie oraz inni), natomiast części zmienne wykonała Schola Cantorum od księży misjonarzy. Prowadzącym, jak i wcześniej przygotowującym te śpiewy był ks. prof. Wendelin Świerczek. Tak opisuje ową sytuację ks. Faustman: „największe zainteresowanie wzbudziła msza chóralna w kolegiacie św. Anny, wykonana przez kilkuset teologów; już zewnętrznie przedstawiał oczom piękny, barwny widok - wśród licznej rzeszy młodego kleru w komżach, zakonnicy w rozmaitych habitach; a to, co wykonywano i śpiewano, było muzyką istotnie niebiańską; śpiewali mszę gregoriańską teolodzy, ro-

\footnotetext{
${ }^{3}$ Zob. „Przegląd Powszechny” 12 (1931) nr 576, s. 387-391; „Hosanna” 6 (1931), s. 109-111.

${ }^{4}$ W. Faustman, Stowo redakcji przed II Wszechpolskim Kongresem Muzyki Kościelnej, „Muzyka Kościelna” 6 (1931) nr 10-11, s. 120.

5 W. Faustman, Drugi Kongres Muzyki Kościelnej w Krakowie, „Muzyka Kościelna” 7 (1932) nr 1, s. 1.

${ }^{6}$ Tamże, s. 9.
} 
zumiejący treść tekstu oraz sens i właściwe piękno chorału”. Jak zauważał w tym właśnie kontekście ks. Michał Kordel, „kongres krakowski to przyniósł pocieszającego, że zainteresowanie się chorałem wzrasta, że zwolenników jego coraz więcej i to wśród świeckich profesorów-muzyków"8.

W dniu drugim kongresu miały miejsce obrady w Domu Katolickim (dzisiejszy budynek Filharmonii Krakowskiej). Rozpoczęły się one od powitania wszystkich oraz wstępu ks. Władysława Wargowskiego jako prezesa Chórów Kościelnych. Wygłoszono też wówczas dwa wiążące referaty: dr A. Szykulanka, delegatka Towarzystwa Muzyki Liturgicznej w Warszawie, mówiła nt. Podstawy odrodzenia muzyki kościelnej w Polsce, jako drugi przemawiał ks. Wacław Faustman, redaktor „Muzyki Kościelnej”, nt. Wjakim kierunku winna pójść praca organistów i chórów w obecnym czasie przesilenia gospodarczego ${ }^{9}$. Kongres zgromadził same znakomitości muzyki kościelnej tamtych czasów. Obecni byli i zresztą zabierali głos w dyskusji m.in. prof. Bronisław Rutkowski, Józef Furmanik czy Feliks Nowowiejski. Po wyczerpaniu dyskusji podjęto także konkretne przesłanie owego muzycznego wydarzenia, a mianowicie: w każdej parafii powinien powstać chór kościelny o charakterze religijno-społecznym, prowadzenie takiego chóru należeć powinno do obowiązków organisty, zaś parafialni duchowni winni takie dzieło wspierać duchowo i materialnie. Dalej zwracano uwage na słuszność prenumeraty „Muzyki Kościelnej” zarówno przez duchownych, jak też organistów i chóry kościelne. W końcu w każdej diecezji powinien istnieć choć jeden reprezentacyjny chór kościelny ${ }^{10}$. Podczas kongresu wykonywano wiele utworów chóralnych kompozytorów polskich, a dość wymienić biorące udział chóry Krakowa: Lutnia, Hasło, Echo Tatrzańskie, Chór Akademicki, Nauczycielski i Towarzystwa Oratoryjnego, Echo Krakowskie, zaś recitale organowe Feliksa Nowowiejskiego, Mistrzyka, Pasierba, Masteli i Profica gromadziły wielkie rzesze słuchaczy. Bowiem, jak pisano wówczas: „chwała Bogu, także w Polsce możemy się już poszczycić całym szeregiem dobrych organistów, niech na tych wzorach inni się uczą i biorą z nich podnietę do pracy w tym kierunku"11.

${ }^{7}$ W. Faustman, Drugi Kongres Muzyki Kościelnej w Krakowie, „Muzyka Kościelna” 7 (1932) nr 1, s. 2.

${ }^{8}$ M. Kordel, Na marginesie II Wszechpolskiego Kongresu Muzyki Religijnej w Krakowie, „Misterium Christi” 1931, s. 132.

${ }^{9}$ Zob. tamże, s. 131.

${ }^{10}$ Zob. W. Faustman, Drugi Kongres Muzyki Kościelnej w Krakowie, „Muzyka Kościelna” 7 (1932) nr 1, s. 4.

${ }^{11}$ W. Faustman, Drugi Kongres Muzyki Kościelnej w Krakowie, „Muzyka Kościelna” 7 (1932) nr 1, s. 2. 
Niestety, jak to zwykle bywa przy takich okazjach, nie brakowało i tych, którzy krytykowali organizację kongresu. Ks. Michał Kordel krytykując stwierdzał jednak, że „program [kongresu] był bardzo bogaty, urozmaicony, doskonale opracowany, a wykonanie wszędzie prawie bez zarzutu. Organizatorzy z ks. W. Wargowskim na czele napracowali się dosyć, co należy z uznaniem podnieść"12. Warto jednak na koniec omawiania owego wielkiego wydarzenia muzycznego 1931 roku, jakie miało miejsce w Krakowie, przytoczyć raz jeszcze słowa jego wielkiego protektora kard. Adama Stefana Sapiehy, który stwierdzał, że: „zadaniem muzyki w kulcie kościelnym jest łączyć wiernych ze świętymi czynnościami liturgicznymi, upiększać je, uprzystępniać przejęcie się tajemnicami, jakie tam się rozgrywają. Wytworzył też on wkoło siebie swą swoistą formę śpiewu i muzyki, które mają ścisły związek z odprawiającymi się funkcjami rytualnymi, a przede wszystkim ze mszą świętą. W liturgii katolik uczestniczy i współdziała w sakramentalnych, symbolicznych, czy pamiątkowych czynnościach i przez wiarę i miłość łączy się z Chrystusem Panem. Toteż ta muzyka wznosi się do najwyższych szczytów natchnienia i sama staje się czymś prawie nadziemskim. Kościół zawsze posiadał swą liturgiczną muzykę, usilnie starał się ją pielęgnować i zalecać, jak to w ostatnich czasach tak epokowo uczynił Papież Pius X. Toteż motu proprio tego Papieża jak również konstytucja Piusa XII winny być podstawą wszelkiej działalności muzycznej w kościele"13.

\section{Ogólnopolski Kongres Muzyki Kościelnej, Toruń 1933}

Zapowiedź kongresu miała miejsce w Krakowie na poprzednim, a miał on odbyć się pod hasłem: Polskiej twórczości ku czci Najświętszej Maryi Panny ${ }^{14}$. Zaś na łamach „Muzyki Kościelnej” w numerze 9-10 z roku 1932 ukazała się zapowiedź, która mówiła: „trzeci ogólnopolski kongres muzyki kościelnej odbędzie się w roku 1933 podczas Zielonych Świąt od 4 do 6 czerwca w Toruniu. Oprócz występów chóru reprezentacyjnego, recitalu organowego, kilku wykładów itp. mają chóry pozamiejscowe możność śpiewania na 30 nabożeństwach w poszczególnych kościołach miasta Torunia"15. Jeszcze w zapowiedzi kongresu, kiedy przedstawiano, jaka będzie jego treść

${ }^{12}$ M. Kordel, Na marginesie II Wszechpolskiego Kongresu Muzyki Religijnej w Krakowie, „Misterium Christi” 1931, s. 128.

${ }^{13}$ W. Faustman, Drugi Kongres Muzyki Kościelnej w Krakowie, „Muzyka Kościelna” 7 (1932) nr 1, s. 10.

${ }^{14}$ Zob. tamże, s. 4.

${ }^{15}$ W. Faustman, Trzeci Ogólnopolski Kongres Muzyki Kościelnej, „Muzyka Kościelna” 7 (1932) nr 9-10, s. 123. 
oraz czego będzie można wysłuchać na koncertach i sympozjum, zwracano się z apelem: „przy tej sposobności zwracamy się do chórów z gorącym apelem, by jak najliczniej brały udział w kongresie i jak najprędzej załatwiły swe zgłoszenia, które przyjmuje ks. Jan Wiśniewski, dyrektor chóru katedralnego w Pelplinie, kierownik artystyczny III Ogólnopolskiego Kongresu Muzyki Kościelnej”16. Kolejny numer „Muzyki Kościelnej” donosił o sensowności i konieczności organizacji Kongresu Muzyki Kościelnej: „są jednakże specjalne przyczyny domagające się zlotu śpiewaków. Zjazd powinien ujawnić i uwypuklić nasz dorobek kulturalny, wykazać nasze postępy"17. Program obejmował wykonanie zwłaszcza muzyki XV i XVII wieku, jak też współczesnych kompozytorów i dlatego już ze wstępnych głosów mówiono, że „kongres zapowiada się okazale”18.

Organizatorem kongresu był ks. Jan Wiśniewski ${ }^{19}$. Na kongres przybyło 80 chórów z całej Polski. Płock reprezentowały dwa chóry: katedralny i szkoły organistowskiej. Na chór katedralny składały się połączone zespoły Seminarium Duchownego i Szkoły Organistowskiej. Połączonymi chórami dyrygował ks. K. Starościński, a na organach akompaniował dyr. M. Karczemny ${ }^{20}$. Swoją obecnością znaczenie kongresu podkreślili znani i cenieni kompozytorzy: Feliks Nowowiejski oraz Wacław Lachmann ${ }^{21}$. Uroczystość rozpoczęła msza celebrowana przez Prymasa Polski w bazylice św. Jana w Toruniu, podczas której kaznodzieja ks. Hieronim Feicht mówił: „o miasto, które się słusznie chlubisz swą siedemsetletnią tradycją kulturalną, a któreś w dziedzinie nauki wydało nawet geniusza w osobie Mikołaja Kopernika, idź w dalszą świetlaną przyszłość pod boską opieką Ducha św. twórczego ducha prawdziwej kultury"22. W tym czasie w wielu świątyniach Torunia rozbrzmiewała dawna i współczesna muzyka chóralna. Przybyło tam bowiem około 60 chórów nie licząc miejscowych, takich jak: Lutnia, Moniuszko, 5 chórów parafialnych oraz Halka z Podgórza, co dało

${ }^{16}$ W. Faustman, Trzeci Ogólnopolski Kongres Muzyki Kościelnej w Toruniu, „Muzyka Kościelna" 8 (1933) nr 1-2, s. 15.

${ }^{17}$ W. Faustman, Kongres Muzyki w Toruniu 4-6 czerwca 1933 roku, „Muzyka Kościelna” 8 (1933) nr 3-4, s. 34.

${ }^{18}$ W. Gieburowski, III Kongres Wszechpolski Muzyki Kościelnej w Toruniu, „Muzyka Kościelna" 8 (1933) nr 3-4, s. 37.

${ }^{19}$ Zob. F. NowowIEJSKI, O znaczeniu Ratyzbony dla ruchu kościelno-muzycznego, „Muzyka Kościelna" 8 (1933) nr 9-10, s. 128.

${ }^{20}$ Zob. J. Domagala, A. Leleń, Kształcenie organistów diecezji płockiej w latach 19022002, Płock 2002, s. 49.

${ }^{21}$ Zob. „Głos Mazowiecki” z 6 czerwca 1933, nr 125, s. 1.

${ }^{22}$ H. FeIcht, Kazanie wygłoszone $w$ bazylice św. Jana $w$ Toruniu na trzecim Kongresie Liturgiczno-Muzycznym, „Muzyka Kościelna” 8 (1933) nr 7-8, s. 91. 
ostateczną ilość osób przekraczającą 400 tysięcy śpiewaków. Najliczniej reprezentowane było Pomorze (27 chórów). Wśród zaś kościelnych dostojników obecnych na kongresie znaleźli się: biskup chełmiński Okoniewski, biskup łomżyński Łukomski oraz prymas Polski August Hlond. Po uroczystej liturgii całe zgromadzenie przeniosło się na rynek staromiejski, gdzie ks. Wiśniewski jako organizator kongresu ogłosił jego otwarcie, kolejno także przemawiali wojewoda pomorski oraz prezydenta miasta. „A po odśpiewaniu przez wszystkich chórzystów Gaude Mater Polonia głos zabrał bp Okoński, mówiąc o znaczeniu muzyki i śpiewu kościelnego i kończąc okrzykiem na cześć Ojca św. W końcu ks. biskup odczytał telegram od nuncjusza papieskiego w Warszawie"23. Na zakończenie tychże uroczystości na rynku w Toruniu chóry wraz z orkiestrą odśpiewały Ojczyznę Feliksa Nowowiejskiego. Po południu tego samego dnia odbył się recital organowy pana Hermańczyka, organisty katedralnego w Pelplinie. Wieczorem, przed uroczystym koncertem muzyki religijnej w teatrze miejskim, miała miejsce defilada, przemarsz wszystkich zebranych chórów. W trakcie tych uroczystych chwil, prócz koncertów oraz sprawowanych liturgii odbyły się także obrady, które miały miejsce w sali obrad Rady Miejskiej. Jako pierwszy głos zabrał ks. Hieronim Feicht, który mówił nt. kościelnej pieśni ludowej, jako kolejny wstąpił ks. Wacław Faustman, który przedłożył wystąpienie na temat: O konieczności organizacji w dziedzinie muzyki kościelnej. Ożywiona była dyskusja, w której wzięli udział: ks. Lewandowski, red. Zygmunt Latoszewski, ks. Jan Wiśniewski, ks. Dreszler, ks. Władysław Wargowski, a na koniec przyjęto przesłanie, iż „obecnie nie powinno być żadnej diecezji bez diecezjalnego związku chórów kościelnych, zwłaszcza tam gdzie istnieją związki organistów”. Następnie uznano „konieczność stałego kształcenia się organistów, dyrygentów i chórów w liturgii, w tym celu jedni i drudzy winni abonować organ nasz «Muzykę Kościelną»”. Kongres zwrócił się w końcu z prośbą do Episkopatu o „ustanowienie komisji diecezjalnej do spraw muzyki kościelnej, o roztoczenie opieki nad fachowym wykształceniem organistów i dyrygentów, o udzielenie komisji dla spraw muzyki kościelnej głosu decydującego przy obsadzaniu stanowisk organistowskich"24. Po zakończeniu kongresu Zygmunt Latoszewski, dyrektor opery poznańskiej, pisał: „był to trzeci z kolei kongres muzyki kościelnej, który jeszcze silniej może, aniżeli poprzednie zjazdy w Poznaniu i Krakowie

${ }^{23}$ W. Faustman, Trzeci Kongres Muzyki Kościelnej w Toruniu, „Muzyka Kościelna” 8 (1933) nr 7-8, s. 94.

${ }^{24}$ Tamże, s. 98.

${ }^{25}$ Z. Latoszewski, III Kongres Muzyki Kościelnej w Toruniu, „Muzyka Kościelna” 8 (1933) nr 7-8, s. 99. 
wykazał żywotność idei, jaka przyświeca pracy chórów kościelnych... dla kultu religijnego, czyli dla służby Bożej, jedynie najgłębsze i najszczersze wysiłki artystyczne są godne powagi miejsca w jakich się odbywają"25. Jedno z ciekawszych wystąpień podczas kongresu to referat ks. Wacława Faustmana na temat „konieczności organizacji w dziedzinie muzyki kościelnej”, w którym autor odkrywał konkretne cele, jakie stawia sobie każde takie właśnie zgromadzanie, a mianowicie: tworzenie chórów kościelnych po parafiach, łączenie ich w związki diecezjalne, grupowanie ich wokół pisma „Muzyka Kościelna”, zaznajamianie ich z polską twórczością i w końcu uświadamianie ich w sprawach liturgicznych ${ }^{26}$.

\section{Polski Kongres Muzyki Gregoriańskiej, Jasna Góra 1958}

Za przyczyną ks. Henryka Nowackiego doszło do skutku wydarzenie na miarę krajową, a mianowicie I Polski Kongres Muzyki Gregoriańskiej na Jasnej Górze w dniach 23-24 września 1958 roku. Wielka praca przygotowawcza do przeprowadzenia w Polsce tego muzycznego wydarzenia wiązała się także z przekonaniem środowiska kościelnego (instytucjonalnego) o wadze przedsięwzięcia. Komitet organizacyjny skierował listy zapraszające na kongres m.in. do biskupów, zabiegając w ten sposób o poparcie inicjatywy organizacji kongresu. „Ponieważ niektórzy wyrażali wątpliwość, czy kongres będzie posiadał zgodę władzy duchownej i czy będzie wolno brać w nim udział osobom zakonnym, zwłaszcza żeńskim, Komitet prosił księdza Prymasa Stefana Wyszyńskiego, aby udzielił ogólnego pozwolenia duchowieństwu całego kraju na wzięcie udziału w kongresie. Biskupi z życzliwością przyjęli tę inicjatywę. Świadczy o tym choćby odezwa arcybiskupa poznańskiego A. Baraniaka, a także udział biskupów w kongresie"27. W samych obradach kongresu brało udział 2,5 tys. uczestników, w całości wzięło udział ok. 5 tys. muzyków kościelnych. Było to pierwsze na taką skalę wydarzenie muzyczne w tamtym okresie.

Choć I Polski Kongres Muzyki Gregoriańskiej nie wiąże się ściśle z tematem niniejszego artykułu, jest on równocześnie kontynuacją tego, co dokonywało się w polskiej muzyce kościelnej; wynika on także z całości ruchu liturgicznego oraz cecyliańskiego, dlatego też nie może zabraknąć tutaj omówienia tego ważnego wydarzenia.

${ }^{26}$ Zob. W. Faustman, O konieczności organizacji w dziedzinie muzyki kościelnej, „Muzyka Kościelna" 8 (1933) nr 7-8, s. 103.

${ }^{27}$ J. ZAwitkowski, Ksiądz Henryk Nowacki, życie i twórczość, [w:] Muzyka Religijna w Polsce. Materiały $i$ studia, t. 1, z. 2, red. J. Pikulik, Warszawa 1976, s. 80. 
Jak pisał wówczas jeden z uczestników: „Kongres muzyki gregoriańskiej był imprezą potrzebną i udaną. Wielka liczba uczestników świadczy o obudzonym w Polsce zainteresowaniu dla śpiewu gregoriańskiego"28. Rozpoczęło się wszystko od nabożeństwa eucharystycznego oraz odśpiewania Veni Creator, tej części przewodniczył generał Zakonu Paulinów o. Ludwik Nowak. Pierwsza cześć kongresu odbywała się pod przewodnictwem bpa Jana Fondalińskiego i złożyły się na nią trzy referaty: ks. prof. T. Miazgi nt. Nauczanie muzyki liturgicznej w seminariach duchownych według myśli $i$ wskazań Kościoła, ks. dra S. Świetlickiego nt. Prawodawstwo muzyczne z uwzględnieniem zwyczajów i spraw Mszy uroczystej, s. mgr S. Szyłkiewicz nt. Rola żeńskich zgromadzeń w odrodzeniu muzyki liturgicznej w Kościele. Dzień drugi kongresu rozpoczął się od uroczystej celebracji mszy świętej, której przewodniczył bp Zdzisław Goliński, a zebrani muzycy kościelni śpiewali chorał gregoriański. Następnie rozpoczęła się uroczysta sesja kongresu, którą rozpoczął ks. dr S. Świetlicki, przemówienia wygłaszali także bp A. Pawłowski, bp S. Jakiel oraz generał paulinów o. L. Nowak. W tym dniu wygłoszono następujące referaty: o. P. Rostworowski OSB nt. Modlitwa liturgiczna a modlitwa prywatna, ks. mgr S. Sprusiński nt. Czynne uczestnictwo wiernych w publicznych modlitwach Kościoła, Koszowski i Jackowski nt. Rola organistów w odrodzeniu śpiewu liturgicznego według myśli Kościoła. W sesji popołudniowej głos zabrali: ks. prof. M. Jankowski nt. Phyta i taśma magnetofonowa w stużbie nauczania i należytego śpiewu gregoriańskiego, ks. prof. Filipowicz nt. Jak w drodze na Jasna Górę nauczytem warszawskich pielgrzymów śpiewać mszę XI, ks. prof. W. Lewkowicz nt. Właściwy akompaniament do śpiewów gregoriańskich. Głos zabrał także ks. prof. T. Miazga omawiając Pierwszeństwo śpiewu gregoriańskiego przed innymi rodzajami śpiewów sakralnych, na końcu ks. prof. G. Mizgalski mówił nt. Troska o muzykę liturgiczna w Polsce na Tysiąclecie z uwzględnieniem starań dotychczasowych. Kongres po odśpiewaniu nieszporów ku czci Najświętszej Maryi Panny został uroczyście zamknięty ${ }^{29}$.

I gdyby ktoś dowodził, że chorał gregoriański w czymkolwiek podważa istnienie pieśni kościelnej wynikającej z pobożności, stwierdzono już w rok po zamknięciu kongresu: „dziś już nikt w Polsce nie lekceważy wartości i roli, jaką ma do spełnienia polska pieśń kościelna. Zdajemy sobie sprawę, że codzienna praktyka, liturgiczne życie w szerszym sensie rozumiane, duszpasterskie od-

${ }^{28}$ F. Mataczyński, Pierwszy Polski Kongres Muzyki Gregoriańskiej na Jasnej Górze 23-24 IX 1958, RBL 6 (1958), s. 548.

${ }^{29}$ Zob. tamże, s. 547-549.

${ }^{30}$ K. Mrowiec, Z problematyki polskiej pieśni kościelnej, RBL 3 (1959), s. 296-297. 
działywanie na wiernych są nasycone ludową pieśnią kościelną. Zdrowy ruch gregoriański, ogarniający nasz kraj w niczym nie podważa jej wartości”’30.

\section{Ogólnopolski Kongres Muzyki Liturgicznej}

\section{Musicam Sacram Promovere, Kraków 2004}

Po 46 latach od poprzedniego wydarzenia, jakim był Kongres Muzyki Gregoriańskiej na Jasnej Górze, po raz pierwszy po reformie muzyki kościelnej przeprowadzonej przez Sobór Watykański II (1963) zorganizowano w Krakowie w dniach 17-19 września 2004 roku I Ogólnopolski Kongres Muzyki Liturgicznej pod hasłem: Musicam sacram promovere (promować muzykę kościelną). Głównym organizatorem tego szczególnego wydarzenia w życiu Kościoła w Polsce było Stowarzyszenie Polskich Muzyków Kościelnych, a współorganizatorem Katedra Muzyki Kościelnej z Papieskiej Akademii Teologicznej w Krakowie. Prezes SPMK ks. prof. Ireneusz Pawlak w swoim słowie zamieszczonym w biuletynie wydanym z okazji kongresu pisał: „rozpoczynający się I Ogólnopolski Kongres Muzyki Liturgicznej ma znaczenie, nie waham się użyć tego słowa, historyczne. Dotąd bowiem, czy to w Polsce, czy też poza jej granicami, odbywały się kongresy, które łączyły się z tematyką albo muzyki kościelnej, albo też szeroko rozumianej muzyki sakralnej"31. Kongres zorganizowano w 1400-lecie śmierci św. Grzegorza Wielkiego, papieża († 604) oraz z okazji rocznicy 25-lecia ukazania się Instrukcji Episkopatu Polski O muzyce liturgicznej po Soborze Watykańskim II (1979). Właściwą ideę owego zgromadzenia muzyków kościelnych z całej Polski nakreślił w swoim liście do uczestników kongresu kard. Franciszek Macharski, metropolita krakowski: „życzę wam więc, by ten czas podsumowania stanu muzyki kościelnej oraz nowych jej perspektyw w polskim Kościele był dla każdego z was bardzo owocny. Oby w tych wszystkich spotkaniach towarzyszył wam powiew Ducha Świętego, byście opuszczając Kraków powracali do swoich rodzinnych środowisk umocnieni oraz z nowymi siłami i zapałem do trwałej dbałości o piękno muzyki liturgicznej w polskich kościołach"32. Takie też były wszystkie dni kongresu. Bowiem z jednej strony była to próba podsumowania tego, co w dziedzinie reformy muzyki dokonano w naszej ojczyźnie, a z drugiej wskazanie na perspektywy dalszego rozwoju. Może więc dobrze się stało, że w sprawozdaniu dla Katolickiej Agencji Informacyjnej (biuletyn rozchodzi się do parafii w Polsce) rzecznik kongresu pisała: „Sobór

${ }^{31}$ I. Pawlak, Stowo Prezesa Stowarzyszenia Polskich Muzyków Kościelnych, [w:] I Ogólnopolski Kongres Muzyki Liturgicznej. Przewodnik, red. R. Tyrała, Kraków 2004, s. 12.

${ }^{32}$ F. Macharski, Stowo Metropolity Krakowskiego, [w:] I Ogólnopolski Kongres Muzyki Liturgicznej. Przewodnik, red. R. Tyrała, Kraków 2004, s. 9. 
Watykański II zwrócił uwagę na to, że muzyka jest integralną częścią liturgii, ale równocześnie otworzył możliwość, by w świątyniach były używane instrumenty inne niż organy. W całym bagażu, który niesiemy od tamtych czasów, znalazły się także instrumenty, które nie mogą być uznawane za liturgiczne, oraz śpiew, który nie jest śpiewem liturgicznym, ale po prostu popularnym. Tu rozpoczął się cały problem. Co jest muzyką liturgiczną, a co już nią nie jest? Czy wszystko to, co było tradycją, historią, bagażem i bogactwem wieków chrześcijaństwa w Polsce, jest już niepotrzebne i trzeba to wyrzucić? A może na tej historii da się jednak coś budować?"33.

Centrum każdego kongresowego dnia była uroczyście sprawowana Eucharystia, którą celebrowali: na rozpoczęcie kongresu w kościele św. Piotra i Pawła kard. Franciszek Macharski (metropolita krakowski), w kolegiacie św. Anny w drugim dniu kongresu bp Stefan Cichy (Przewodniczący Komisji Kultu Bożego i Dyscypliny Sakramentów Konferencji Episkopatu Polski), a w trzecim w katedrze wawelskiej bp Marcjan Trofimiak z Ukrainy (Przewodniczący Komisji ds. Liturgii Konferencji Episkopatu Ukrainy). Całość kongresu zakończyła się uroczystymi nieszporami w bazylice mariackiej (specjalnie napisanymi na tę uroczystość przez Mariana Machurę, tynieckiego organistę), które poprowadził bp Zbigniew Kiernikowski (biskup diecezjalny z Siedlec). Przygotowana liturgia tak była sprawowana, że wierni brali w niej czynny udział poprzez śpiew pieśni pod przewodnictwem kantora, śpiewający chór (w pierwszym dniu był to chór Psalmodia Papieskiej Akademii Teologicznej w Krakowie pod dyr. Włodzimierza Siedlika, w drugim Chór Mariański z Krakowa pod dyr. Jana Rybarskiego, a w trzecim schola gregoriańska z Białej Podlaskiej oraz Siedlec pod dyr. Piotra Karwowskiego i ks. Piotra Paćkowskiego). Modlitwę animowała schola (w pierwszym dniu schola sióstr zakonnych Krakowa pod dyr. s. Ligii Bender, sercanki, a w drugim uczniowie Archidiecezjalnej Szkoły Organistowskiej w Krakowie pod dyr. Wiesława Delimata). Podczas liturgii rozbrzmiewała także muzyka organowa. Za organami zasiedli: w kościele św. Piotra i Pawła Mieczysław Tuleja, w kościele św. Anny Łukasz Kmiecik, w bazylice mariackiej Witold Zalewski oraz Wiesław Delimat. Chorał gregoriański podczas liturgii w wawelskiej katedrze śpiewany był a cappella. Z tego właśnie centrum wywodziły się niejako poszczególne dni sympozjum z wykładami, referatami oraz panelami dyskusyjnymi, a uzupełnieniem stały się dwa koncerty muzyki chóralnej i organowej.

Bardzo ważnym elementem kongresu Muzyki Liturgicznej w Krakowie była sesja naukowa, która miała miejsce w auli im. Jana Pawła II kra-

${ }^{33}$ M. Dobrzyniak, Sztuka wielka dla wielu. I Ogólnopolski Kongres Muzyki Liturgicznej, „Wiadomości KAI” 652 (2004), s. 9. 
kowskiego seminarium duchownego. Poruszone zostały tematy: Relacja sztuki i liturgii przez prof. Marka Dyżewskiego z Akademii Muzycznej we Wrocławiu, Dokumenty Kościoła w Polsce nt. muzyki kościelnej przez ks. dra Roberta Tyrałę z Papieskiej Akademii Teologicznej w Krakowie, Stużebna funkcji muzyki w księgach liturgicznych w języku polskim po Soborze Watykańskim II przez ks. prof. dra hab. Stanisława Czerwika z Kielc, Edukacja i formacja liturgiczno-muzyczna przez dra Remigiusza Pośpiecha z Uniwersytetu Opolskiego, Inkulturacja w obszarze muzyki liturgicznej wobec wyzwań wspótczesnej muzycznej pop-kultury przez ks. prof. dra hab. Andrzeja Zająca z Papieskiej Akademii Teologicznej w Krakowie.

Prof. Marek Dyżewski przestrzegał polskich muzyków kościelnych przed patologiami „nieszczęsnego daru wolności” twórców muzyki, którzy zbyt często przejmują wzorce z kultury ułatwionej, zbanalizowanej i popularnej. Dyskoteka wdziera się do świątyń, a piosneczki śpiewane na biwakach wypierają chorał, Bacha i Mozarta ${ }^{34}$. Wykład drugi, to przypomnienie polskich dokumentów Kościoła na temat muzyki kościelnej. Do wyjątków, zdaniem autora, należą listy biskupów poświęcone muzyce, trudno też spotkać dziś proboszczów, którzy wykorzystywaliby dane im przez Kościół uprawnienia do dbałości o jakość muzyki rozbrzmiewającej w czasie mszy świętych i obrzędów sakramentalnych ${ }^{35}$. W podsumowaniu autor wystąpienia mówił: „wiele od czasów reformy soborowej w dziedzinie liturgii i muzyki się dokonało. Zwołano II Synod Plenarny, zakończyły się obrady 30 synodów diecezjalnych oraz pierwszego prowincjalnego. Biskupi konkretnych diecezji wydali regulaminy czy statuty dla organistów, także wydano rozmaite dekrety dotyczące organizacji muzyki kościelnej, jeden z polskich biskupów napisał list pasterski na temat muzyki. Ale, czy to wystarcza? Czy i w jaki sposób ta cała teoria realizuje się w poszczególnych parafiach Kościoła w Polsce? Tak wiele zależy od współpracy duchownych i świeckich w tej dziedzinie. Tak wiele zależy od ich porozumienia. Należy wyrazić jedynie nadzieję, iż nowe czasy niosą nowe wyzwania do pomocniczego działania w Kościele, do jedności i troski o wspólne dobro, o skarbiec, jakim jest także muzyka liturgiczna" ${ }^{36}$. Ks. prof. Stanisław Czerwik apelował o kontynuację prac nad śpiewnikiem liturgicznym dla Kościoła w Polsce. W swoim wystąpieniu mówił: „przed Podkomisją Episkopatu Polski ds. Muzyki Sakralnej, przed komisjami diecezjalnymi, przed muzykologami i muzykami stoi pilne

${ }^{34}$ Zob. tamże.

${ }^{35}$ Zob. K. MikLaszewski, I Ogólnopolski Kongres Muzyki Liturgicznej Musicam Sacram Promovere, „Ruch Muzyczny” 21 (2004), s. 8.

${ }^{36}$ R. Tyrała, Dokumenty Kościoła w Polsce o muzyce liturgicznej, [w:] Musicam Sacram Promovere. Studia, t. 1, red. R. Tyrała, Kraków 2004, s. 17. 
zadanie uporządkowania repertuaru śpiewów wykonywanych w liturgii i skomponowania śpiewów, których brak jest ciągle odczuwalny (śpiewów dostosowanych do cyklu misteriów Chrystusa w roku liturgicznym; śpiewów ku czci świętych; śpiewów przewidzianych w liturgii sakramentów i sakramentaliów). Należałoby kontynuować dzieło rozpoczęte przez publikację Śpiewnika liturgicznego sprzed trzynastu lat (1991), byśmy się dopracowali publikacji jednolitej i dostępnej dla wszystkich uczestników posoborowej liturgii, w kształcie podobnym do niemieckojęzycznego Gotteslob. Księga ta winna by się stać nieodstępnym towarzyszem osób odpowiedzialnych za kształtowanie liturgii (jak wczesnośredniowieczny Comes!) obok dotychczasowych ksiąg liturgicznych w języku polskim"37. Remigiusz Pośpiech z Uniwersytetu Opolskiego bardzo podkreślając jedność liturgii z muzyką wskazywał na istotne znaczenie edukacji poprzez dobrą muzykę, rozwoju wręcz wiary. Przypomniał on, że w szkołach klasztornych zdyscyplinowane nauczanie muzyki było kiedyś prowadzone trzy razy w tygodniu lub co dzień po godzinie, dziś zaś nauka religii powinna być nauką śpiewu liturgicznego i czynnego, śpiewanego uczestnictwa we mszy świętej, wreszcie że współcześnie kompozytorzy, piszący muzykę kościelną, winni starannie zapoznać się z liturgią ${ }^{38}$. Ważnym więc wydaje się stwierdzenie tego opolskiego muzykologa, który mówił: „bardzo wyraźnie widać obecność integralnego związku pomiędzy edukacją a formacją. Ojcowie Kościoła, obejmując swoją troską te niezwykle istotne dla liturgicznej służby Bożej elementy działalności duszpasterskiej doskonale rozumieli, że tylko ich pełna symbioza gwarantuje w efekcie kształcenie wartościowych muzyków kościelnych, przy czym obydwa składniki są w pełni równoważne i wzajemnie się dopełniające... jeżeli edukacja - w zakresie muzyki kościelnej - nie pójdzie w parze $\mathrm{z}$ formacją, wtedy będziemy mieli do czynienia $\mathrm{z}$ istotnie zubożoną osobowością muzyków kościelnych, którzy wykonywać będą jedynie swój zawód, zamiast szczególnej posługi liturgicznej”"39. Jako ostatni wystąpił ks. prof. dr hab. Andrzej Zając, który przeprowadził analizę kultury masowej wobec muzyki religijnej. Konkludując swoją wypowiedź mówił: „Czy muzyka mająca cechy kultury masowej może być w obszarze liturgii przedmiotem inkulturacji? Jeżeli tak, to w jakim zakresie? Czy dysponujemy jakimiś narzędziami, które pozwolą nam określić, jakie elementy

${ }^{37}$ S. Czerwik, Stużebna funkcja muzyki w Księgach liturgicznych w języku polskim po Soborze Watykańskim II, [w:] Musicam Sacram Promovere. Studia, red. R. Tyrała, t. 1, Kraków 2004.

${ }^{38}$ Zob. K. MikLaszewski, I Ogólnopolski Kongres Muzyki Liturgicznej Musiam Sacram Promovere, „Ruch Muzyczny” 21 (2004), s. 8.

${ }^{39}$ R. PośPIECH, Edukacja i formacja liturgiczno-muzyczna, [w:] Musicam Sacram Promovere. Studia, t. 1, red. R. Tyrała, Kraków 2004, s. 63. 
muzycznej kultury masowej mogą być przedmiotem inkulturacji, a jakie nie? Jakie są granice inkulturacji i kto (lub co) je określa? Odpowiedź na te pytania nie jest prosta, problem bowiem jest niezwykle złożony. Dotyczy bowiem z jednej strony wytworów masowej kultury muzycznej, które różnią się między sobą genezą, estetyką, światopoglądem, stosunkiem do spraw religii; muzyki związanej często z ruchami anarchistycznymi, kontestacyjnymi, z anty- czy subkulturą, której nieodłącznymi elementami są narkotyki, alkohol i wyuzdany seks, a nawet muzyki związanej wprost z kultami satanistycznymi. Z drugiej zaś strony mamy obszar szczególnego sacrum, jakim jest liturgia, obszar właściwy dla religijnych zachowań człowieka: modlitwy, celebracji tajemnic wiary, doświadczeń bliskości Boga itp., sferę, w której według zdrowego odczucia ludzi wierzących nie ma miejsca na rozrywkę, zabawę, erotyzm czy zachowania typowe dla świeckiej aktywności człowieka. Jak zatem pogodzić te dwie jakże odległe od siebie dziedziny ludzkiego życia i ludzkich zachowań?"

Dopełnieniem wykładów, równocześnie cieszącym się wielkim zainteresowaniem uczestników, były dyskusje panelowe na temat: monodii liturgicznej, muzyki wokalnej i wokalno-instrumentalnej, muzyki instrumentalnej ze szczególnym miejscem dla organów piszczałkowych, śpiewników kościelnych, nowych ksiąg liturgicznych, nauczania muzyki, miejsca i roli w liturgii kantora i organisty, chóru, scholi, zespołów instrumentalnych, imprimatur i praw autorskich i w końcu na temat transmisji liturgii przez radio i telewizję. Brali w niej udział zaproszeni goście, jak również wszyscy chętni uczestnicy kongresu. To była prawdziwa eksplozja myśli i prób rozwiązań problemów muzyki kościelnej w Polsce. Na zakończenie sesji naukowej przybył kard. Stanisław Nagy SCJ, który podziękował wszystkim za wysiłki, by muzykę kościelną uczynić ewangelizacyjną drogą Kościoła w świecie współczesnym.

Wszystkim obradom towarzyszyły dwa koncerty. W piątek 17 września w bazylice Ojców Franciszkanów odbył się koncert chóralny. Przedstawiono dwa chóry, z dwóch stowarzyszeń chórów kościelnych, mianowicie chór Epifania z parafii Miłosierdzia Bożego w Warszawie pod dyr. Wiesława Jelenia, który reprezentował Związek Chórów Kościelnych Caecilianum ${ }^{41}$, a dyrygent jest obecnym prezesem owego stowarzyszenia. Jako drugi wystąpił chór Pueri Cantores S. Nicolai z Bochni pod dyr. ks. Stanisława

${ }^{40} \mathrm{~A}$. ZAJĄC, Inkulturacja w obszarze muzyki liturgicznej wobec wyzwań wspótczesnej popkultury, [w:] Musicam Sacram Promovere. Studia, t. 1, red. R. Tyrała, Kraków 2004, s. 71

${ }^{41}$ Zob. A. Filaber, Caecilianum w Polsce, LS 1-2 (1995), s. 135-139.

${ }^{42}$ Zob. A. ZAJĄC, Ruch Pueri Cantores spadkobierca i kontynuatorem kulturowej i liturgicznej tradycji Kościoła, LS 1 (2002) nr 8, s. 89-105. 
Adamczyka, jako reprezentant Polskiej Federacji Pueri Cantores $^{42}$. Prowadzący koncert ks. prof. Andrzej Zając słusznie podkreślał: „obydwa stowarzyszenia działają na polu religijnej muzyki chóralnej, a ich celem jest propagowanie śpiewu chóralnego w liturgii i podczas koncertów. Śpiew chóralny jest bowiem niezbędnym elementem uroczystej liturgii Kościoła; dowodzi tego wielowiekowa kościelna tradycja, a jego znaczenie podkreślają dokumenty Kościoła dotyczące muzyki liturgicznej. Muzyka chóralna jest także ważnym elementem religijnej kultury muzycznej, kształtowanej przez wieki aż po czasy nam współczesne. I w te dwa obszary religijnej muzyki chóralnej wpisują swoją działalność Caecilianum i Polska Federacja Pueri Cantores"43. Drugi koncert odbył się 18 września 2004 roku i miał miejsce w bazylice św. Floriana, był to koncert organowy. Za instrumentem zasiedli uczeń i mistrz, a mianowicie mgr Arkadiusz Bialic oraz prof. Józef Serafin. Pierwszy „wykorzystał skromny pogłos świątyni, by podkreślić bogactwo artykulacyjne muzyki Sweelincka i taneczne pochodzenie szybkiej części Sonaty e-moll Bacha, Józef Serafin dokonał fascynującego zestawienia: chorał Nun komm der heiden Heiland zaprezentował najpierw w opracowaniu Buxtehudego, potem Bacha - na zakończenie zaś udowodnił, że nawet na niedoskonałym instrumencie Passacaglia c-moll Bacha porusza słuchaczy do głębi i może przyczynić się do pełniejszego przeżycia modlitwy"44.

Uczestnikami I Ogólnopolskiego Kongresu Muzyki Liturgicznej Musicam Sacram Promovere byli duchowni i świeccy muzycy kościelni ze wszystkich prawie ośrodków w Polsce, było to przeszło 600 osób. Po dokonaniu tego wydarzenia, ważne, by te wszystkie przemyślenia i refleksje nie skończyły się tylko na podsumowaniach, słowach. Potrzebne sa tutaj czyny. Dlatego pewnie ciekawe będzie przełożenie dokonań kongresowych na realia kościoła parafialnego, kaplicy domu zakonnego czy seminarium, tam gdzie sprawuje się liturgię. To tam bowiem okaże się, czy mocne stwierdzenie konstytucji Sacrosanctum Concilium, że „muzyka jest integralną częścią uroczystej liturgii” (nr 112),jest rzeczywistością czy też tylko teorią. W tym względzie bardzo potrzebna jest edukacja, nieustające dokształcanie muzyków: organistów, dyrygentów chórów, kantorów, psałte-

${ }^{43}$ A. ZAJĄC, Koncert w przestrzeni sakralnej kościoła - refleksje na kanwie Instrukcji o koncertach Kongregacji Kultu Bożego, [w:] Musicam Sacram Promovere. Studia, t. 1, red. R. Tyrała, Kraków 2004, s. 115.

${ }^{44}$ K. Miklaszewski, I Ogólnopolski Kongres Muzyki Liturgicznej Musiam Sacram Promovere, „Ruch Muzyczny” 21 (2004), s. 9. 
rzystów, śpiewających w scholi, ale również i duchownych. „Jeśli zaczniemy przejmować się pięknem liturgii, którą najpierw przygotowujemy, a potem sprawujemy, jeśli nie będzie ona prywatną sprawą celebransa, ale całej wspólnoty Kościoła, to muzyka kościelna będzie promowana właściwie. Będzie znakiem czytelnym, stanie się sposobem na jedność, nie będzie czymś przypadkowym i nudnym"45.

Kraków

KS. ROBERT TYRALA

${ }^{45}$ R. TyraŁa, I Ogólnopolski Kongres Muzyki Liturgicznej Musicam Sacram Promovere, „Vita Academica” 5-6 (2004), s. 11. 